International Journal of Translational

Medical Research and Public Health (2019), Volume 3, Issue I, 3 I-37

\begin{tabular}{ll}
\hline INTERNATIONAL JOURNAL OF TrANSLATIONAL \\
IJTMRPICAL RESEARCH AND PUBLIC HEALTH \\
ISSN 2576-9502 (Online) \\
ISSN 2576-9499 (Print) \\
\end{tabular}

ORIGINALARTICLE

\title{
Body Mass Index and Breast Cancer Risks Among Igbo Women in Imo and Abia States, Nigeria:A Case Control Study
}

\author{
Christopher S. Oyamienlen, MPH; ${ }^{\bowtie}$ Charles A.Adisa, MD;' Ikechukwu N. S. Dozie, PhD;² \\ Evangeline T. Oparaocha, PhD; ${ }^{2}$ Angelica A.Anele MD; ${ }^{3}$ Kingsley C.Anochiwa, $\mathrm{MPH}^{4}$ \\ 'Abia State University Teaching Hospital,Aba, Ayaba Umueze Road, PMB 7004,Abia State, Nigeria; ${ }^{2}$ Department of Public Health Technology, School of \\ Health Technology, Federal University of Technology, Owerri, Imo State, Nigeria; ${ }^{3}$ Breast Oncology Unit, Federal Medical Centre, Owerri, Orlu Road, Imo \\ State, Nigeria; ${ }^{\text {P}}$ athology Department, Federal Medical Centre, Owerri, Orlu Road, Imo State, Nigeria. \\ Corresponding author email: Chriswebren@gmail.com
}

\section{ABSTRACT}

Background: The association between body mass index (BMI) and breast cancer risk has been well recognized. The purpose of this study was to determine the association of BMI with breast cancer risks among women of Igbo origin in Imo and Abia states in South Eastern Nigeria.

Methods:The study was conducted at three different locations:Abia State University Teaching Hospital Aba, Abia State; Federal Medical Centre, Owerri, Imo State; and the Maranatha Specialist Mission Hospital, Aba, Abia State. This was a prospective hospital-based case control study. Data were collected on sociodemographic characteristics and anthropometric measures using a structured questionnaire. Collected data were imported to SPSS version 23 for analysis. In all, 68I patients participated in the study of which 347 were cases and 334 were controls. The $T$-test was used to assess statistical differences of height, weight, and $\mathrm{BMI}$ in the studied groups. Logistic regressions were used to calculate the multivariate odds ratio $(O R)$ using $95 \%$ confidence interval $(C l)$ with significant level set at $p>0.05$.

Results: Higher BMI is associated with increased risk of breast cancer. There was a significant statistical difference between the height of cases and controls in both pre-and post-menopausal women. The mean value of height was $161.14 \pm 7.1 \mathrm{~cm}$ among cases compared to controls which was $161.39 \mathrm{~cm}(p<0.05)$. The mean weight among cases was $66.34 \pm 11.8 \mathrm{~kg}$ compared to controls at $65.45 \pm 9.2 \mathrm{~kg}(p<0.05)$; the mean BMI was $25.6 \pm 4.8 \mathrm{~kg} / \mathrm{m}^{2}$ among cases compared to controls $25 . \mathrm{I} \pm 4.6 \mathrm{~kg} / \mathrm{m}^{2}(p<0.05)$.

Conclusion and Implications For Translation: Primary prevention measures are important to modestly curtail the increasing burden of obesity and high BMI. By controlling the weight, through physical activities, changes in diet and modestly alcohol intake will reduce the risk of breast cancer.

Key words: Breast Cancer • Imo State • Abia State • South East Nigeria • Body Mass Index • Nigeria

Copyright (C) 2019 Oyamienlen et al. This is an open-access article distributed under the terms of the Creative Commons Attribution License, which permits unrestricted use, distribution, and reproduction in any medium, provided the original work is properly cited. 


\section{I.Introduction}

\section{I.I. Background of the Study}

Breast cancer is predominantly a disease of women and has a major impact on their health. Globally breast cancer accounts for $25.1 \%$ of all cancers in women ranking second (II.9\%) overall when both sexes are considered together.'

Body Mass Index (BMI) is the weight in kilograms divided by the square of height in meters. BMI is a marker for general adiposity. ${ }^{2} \mathrm{BMI}$ is categorized into underweight $\left(\mathrm{BMl}<18.5 \mathrm{~kg} / \mathrm{m}^{2}\right)$, normal range $\left(18.5-24.9 \mathrm{~kg} / \mathrm{m}^{2}\right)$, overweight $\left(25-30 \mathrm{~kg} / \mathrm{m}^{2}\right)$, and obese $\left(B M I \geq 30 \mathrm{~kg} / \mathrm{m}^{2}\right)$ as defined by World Health Organization (WHO) BMI classification. ${ }^{3}$ In Nigeria, there are scanty studies on the association between breast cancer and BMI. The studies by Adebamowo et $\mathrm{al}^{4}$ and Ogundiran et $\mathrm{a}^{5,6}$ were done at the South Western part of Nigeria and there are no similar studies conducted in the South Eastern part of Nigeria. Result of the study done by Adebamowo et $\mathrm{al}^{4}$ shows that there is no association between obesity and breast cancer risk.

In other parts of the world specifically Europe, USA, and Australia, many epidemiological studies have shown that obesity is associated with a significantly elevated breast cancer risk. ${ }^{7,8}$ High BMI appears to be associated with increased breast cancer risk in postmenopausal women while it has slightly protective effect on pre-menopausal women.9,10 Considering the fact that there are limited studies on breast cancer risk and BMI association in Nigeria and none among Igbo women in Abia State and Imo State, this study became imperative to look at the association between $\mathrm{BMI}$ and breast cancer risk among the Igbo women.

According to the predictions made by Ferlay et al ' and Bray et al', there would be 52,728 female breast cancers in Nigeria in 2035 accounting for about $25 \%$ of all female cancers. Among the three population based cancer registries established in Nigeria, breast cancer of the females top the list of cancers at Ibadan, Oyo State; Abuja, Federal Capital Territory; and Calabar, Cross River State. The risk of developing breast cancer is associated with several factors such as increasing age, family history, exposure to female reproductive hormones (both endogenous and exogenous), dietary factors, benign breast disease, environmental factors, early age at menarche, nuliparity or late age at first delivery, late age at postmenopausal, obesity and postmenopausal hormone therapy. ${ }^{12}$

\section{I.2. Objectives of the Study}

The study was designed to determine the association between $\mathrm{BMI}$ and breast cancer risk among lgbo women living in Abia and Imo States, Nigeria. We define risk factors of breast cancer as factors that increase the risk of breast cancer. These include age, family history, medical history, weight, physical activities, diet, smoking, exposure to estrogen, stress, anxiety, and alcohol consumption, among others.

\section{I.3. Specific Aims and Hypothesis}

Specific Aims: Our specific aims were to: I) Determine the association between $\mathrm{BMI}$ and premenopausal breast cancer risks; 2) Determine the association between $\mathrm{BMI}$ and postmenopausal breast cancer risks; 3) Determine the association between height and breast cancer risks; and 4) Determine the association between weight and breast cancer risks for pre- and postmenopausal women.

Research Hypotheses: We posed the following research hypotheses:

I) There is no significant association between BMI and breast cancer risk among pre- menopausal women;

2) There is no significant association between BMI and breast cancer risk among postmenopausal women;

3) There is no significant association between height and breast cancer risk among women; and that

4) There is no significant association between weight and breast cancer risk among women in the study.

\section{Methods}

The study was a prospective hospital based casecontrol study conducted between October 2014 and August 2016. Information on exposure factors 
was collected from all the confirmed and suspected cases of breast cancer during the period; cases confirmed microscopically to have malignancy were included in the study. Frequency match was used for age and BMI.The data were collected for two years. Pre-designed case and control registration forms were used to collect the information. There was anthropometry measurement. Control was collated at the same hospitals.

\section{I. Study Population}

The study population was premenopausal and postmenopausal Igbo women attending Abia State University Teaching Hospital, Aba; the Maranatha Specialist Hospital, Aba; and Federal Medical Centre, Owerri, Imo State. As at 2012, five years prevalence of all cancer in Nigeria is 225,000 (53.1\%). " In all, $68 \mathrm{I}$ women were enrolled into the study. There were 347 breast cancer cases diagnosed and 344 controls managed in the health facilities were enrolled in the study. Purposive sampling method was used to select tertiary health institutions and a referral center for breast cancer in Imo and Abia States. All statistical analysis were performed using Statistical Package for Social Sciences (SPSS) version 23 software package ${ }^{13}$ Quantitative data were expressed as numbers and percentages while qualitative standards were expressed as Mean \pm Standard Deviation(SD). Independent T-Test was used to assess statistical differences in height, weight and BMI in studied group. Based on the BMI, women were grouped into four categories in which the odds ratio were calculated to find risk estimation between the group of BMI in both pre and postmenopausal women separately. Multiple logistic regression analysis was conducted to estimate the odds ratio for developing breast cancer and $95 \%$ confidence interval for variables. The second BMI category was used as a reference category. Less than 0.05 was regarded as significant statistical level.

\subsection{Ethical Approval}

The study received ethical approval from the Department of Public Health, Federal University of Technology Owerri, Abia State University Teaching Hospital,Aba,The Maranatha Specialist Hospital,Aba, and the Federal Medical Center, Owerri. Written informed consent was sought and obtained from each subject. Participation was voluntary and the study did not involve invasive procedures or the alteration of standard clinical care.

\section{Results}

Table I shows the frequency distribution for BMI for the total population and for pre- and postmenopausal women. Of the $68 \mathrm{I}(100 \%)$ subjects studied, 345(50.7) were cases and 336(49.3\%) were controls. The overall mean height and weight difference were 161.39 \pm 6.6 and $65.9 \pm 10.6$, respectively. The subjects' BMI for underweight, normal, overweight and obese for cases were 17(5.0), 162(46.9), 99(28.7) and 67(19.4), respectively. The subjects' BMI for underweight, normal, overweight and obese for controls were 16(4.8), 152(45.2), I 3 | (39.0), 37( | I.0), respectively.

\section{I. Difference in Height, Weight and BMI}

Table 2 presents the differences in height, weight and BMI between cases and controls for premenopausal and postmenopausal women. The premenopausal mean height for cases was $159.9 \pm 8.0$ compared to controls $|6| .7 \pm 5.6(p<0.009)$; weight was $65.6 \pm \mid 3.0$ compared to controls 65.7 $\pm 9.1 \quad(p<0.000 \mathrm{I})$; and BMI was $25.7 \pm 5.3$ compared to controls $25.2 \pm$ $3.8(p<0.000 \mathrm{I})$. When the mean height difference between cases and controls subjects were evaluated, a significant difference was observed indicating that the mean height was higher for pre-menopausal controls compared to cases and lower for postmenopausal controls compared to cases with $(p<009)$.

\subsection{Association between Breast Cancer Risks and $\mathrm{BMI}$}

Table 3 shows the association between breast cancer risk and BMI.There was a positive association between $\mathrm{BMI}$ and breast cancer risk and the risk is stronger for postmenopausal subjects compared to premenopausal subjects. The odds of developing breast cancer for women in the premenopausal category were 1.74, 1.50, and 2.21 higher for underweight, overweight and obese, respectively compared to controls, while the odds of developing breast cancer for women in the postmenopausal 
Oyamienlen et al. International Journal of Translational Medical Research and Public Health (20I9), Vol. 3, No. I, 3 I-37

Table I: Frequency Distribution for BMI Category

\begin{tabular}{|c|c|c|c|c|c|}
\hline Measurement & Frequency (\%) & Mean & STD & Cases (\%) & Controls (\%) \\
\hline Height & $681(100)$ & 161.39 & 6.6 & $345(50.7)$ & $336(49.3)$ \\
\hline Weight & $681(100)$ & 65.9 & 10.6 & $345(50.7)$ & $336(49.3)$ \\
\hline \multicolumn{6}{|l|}{ BMI } \\
\hline Underweight & $33(4.8)$ & & & $17(5.0)$ & $16(4.8)$ \\
\hline Normal & $314(46.1)$ & & & $162(46.9)$ & $152(45.2)$ \\
\hline Overweight & $230(33.8)$ & & & $99(28.7)$ & $131(39.0)$ \\
\hline Obese & $104(15.3)$ & & & $67(19.4)$ & $37(\mathrm{II} .0)$ \\
\hline Total & $681(100)$ & 25.4 & 4.4 & $345(50.7)$ & $336(49.3)$ \\
\hline \multicolumn{6}{|c|}{ Premenopausal } \\
\hline Underweight & $14(5.6)$ & & & $8(6.2)$ & $6(5.1)$ \\
\hline Normal & $114(46.0)$ & & & $61(46.9)$ & $53(44.9)$ \\
\hline Overweight & $78(3 \mid .5)$ & & & $33(25.4)$ & $45(38.1)$ \\
\hline Obese & $42(16.9)$ & & & $28(21.5)$ & $14(11.9)$ \\
\hline Total & $248(100)$ & 2.6 & 0.82 & $130(100)$ & $118(110)$ \\
\hline \multicolumn{6}{|c|}{ Postmenopausal } \\
\hline Underweight & $19(4.4)$ & & & $9(4.2)$ & $10(4.6)$ \\
\hline Normal & $200(46.2)$ & & & 101 (47) & $99(45.4)$ \\
\hline Overweight & $152(35.1)$ & & & $66(30.7)$ & $86(39.4)$ \\
\hline Obese & $62(14.3)$ & & & $39(18.1)$ & $23(10.6)$ \\
\hline Total & $433(100)$ & 2.6 & 0.79 & $215(100)$ & $218(100)$ \\
\hline
\end{tabular}

Table 2: Height, Weight and BMI Difference between Cases and Controls for Premenopausal and Postmenopausal Women

\begin{tabular}{lcccr}
\hline Measurement & Cases (Mean) $\pm S D$ & Controls (Mean) $\pm S D$ & $P$-value & $T$-test \\
\hline Premenopausal Height & $159.9 \pm 8.0$ & $161.7 \pm 5.6$ & 0.009 & 2.066 \\
\hline Weight & $65.6 \pm 13.0$ & $65.7 \pm 9.1$ & 0.000 & 0.139 \\
\hline BMI & $25.7 \pm 5.3$ & $25.2 \pm 3.8$ & 0.000 & 0.891 \\
\hline Postmenopausal Height & $161.9 \pm 6.4$ & $161.6 \pm 6.2$ & & 0.430 \\
\hline Weight & $66.8 \pm 10.9$ & $65.3 \pm 9.4$ & & 1.560 \\
\hline BMI & $25.6 \pm 4.5$ & $25.1 \pm 4.1$ & & 1.170 \\
\hline BMI Total Height & $161.1 \pm 7.1$ & $161.6 \pm 6.0$ & $<0.470$ & 1.000 \\
\hline Weight & $66.3 \pm 11.8$ & $65.4 \pm 9.3$ & $<0.000$ & 1.100 \\
\hline BMI & $25.6 \pm 4.8$ & $25.1 \pm 4.0$ & $<0.001$ & 1.600 \\
\hline
\end{tabular}

category were 1.66 and 2.72 higher for underweight and obese women compared to controls (Figure I).

\subsection{BMI categories in pre- and postmenopausal breast cancer risk among women}

There was a total of 347 cases and 336 controls overall, in both pre-and postmenopausal women.
Breast cancer risk was increased by increasing $\mathrm{BMI}$, but the risk was more pronounced among postmenopausal than premenopausal women, especially for women with BMI more than $30 \mathrm{~kg} / \mathrm{m}^{2}$. The results of multiple logistic regression show that a high BMI (more than $30 \mathrm{~kg} / \mathrm{m}^{2}$ ) was positively correlated with risk of breast cancer 
$\mathrm{BMI}$ and breast cancer risks

Table: 3 Associations between Breast Cancer Risks and Body Mass index (BMI)

\begin{tabular}{|c|c|c|c|c|c|c|}
\hline Measurement & $\mathbf{N}(\%)$ & Cases (\%) & Control (\%) & Odds ratio & $p$-value & $95 \% \mathrm{Cl}$ \\
\hline \multicolumn{7}{|c|}{ Premenopausal } \\
\hline Normal & II (46.0) & $61(46.9)$ & $53(44.9)$ & I-ref & 0.034 & \\
\hline Underweight & $14(5.6)$ & $8(6.2)$ & $6(5.1)$ & 1.740 & 0.143 & $0.829-3.641$ \\
\hline Overweight & $78(31.5)$ & $33(25.4)$ & $45(38.1)$ & 1.500 & 0.521 & $0.435-5.172$ \\
\hline Obese & $42(16.9)$ & $28(21.5)$ & 14 (II.9) & 2.210 & 0.120 & $1.246-5.970$ \\
\hline Total & $248(100)$ & $130(100)$ & $118(100)$ & & & \\
\hline \multicolumn{7}{|c|}{ Postmenopausal } \\
\hline Normal & $200(46.2)$ & $101(47.0)$ & $99(45.4)$ & I-ref & 0.045 & \\
\hline Underweight & $19(4.4)$ & $9(4.2)$ & $10(4.6)$ & 1.660 & 0.089 & $0.930-2.980$ \\
\hline Overweight & $152(35.1)$ & $66(30.7)$ & $86(39.4)$ & 1.880 & 0.231 & $0.668-5.317$ \\
\hline Obese & $62(14.3$ & $39(18.1)$ & $23(10.6)$ & 2.720 & 0.010 & $1.204-4.054$ \\
\hline Total & $433(100)$ & $215(100)$ & $218(100)$ & & & \\
\hline \multicolumn{7}{|l|}{ BMI Total } \\
\hline Normal & $314(46.1)$ & $162(46.9)$ & $152(45.2)$ & I-ref & 0.004 & \\
\hline Underweight & $33(4.8)$ & $17(5.0)$ & $16(4.8)$ & 1.700 & 0.023 & $1.070-2.690$ \\
\hline Overweight & $230(33.8)$ & $99(28.7)$ & $13 \mid(39.0)$ & 1.700 & 0.187 & $0.772-3.763$ \\
\hline Obese & $104(15.3)$ & $67(19.4)$ & $37(11.0)$ & 2.396 & 0.000 & I.480-3.868 \\
\hline Total & $681(100)$ & $345(100)$ & $336(100)$ & & & \\
\hline
\end{tabular}

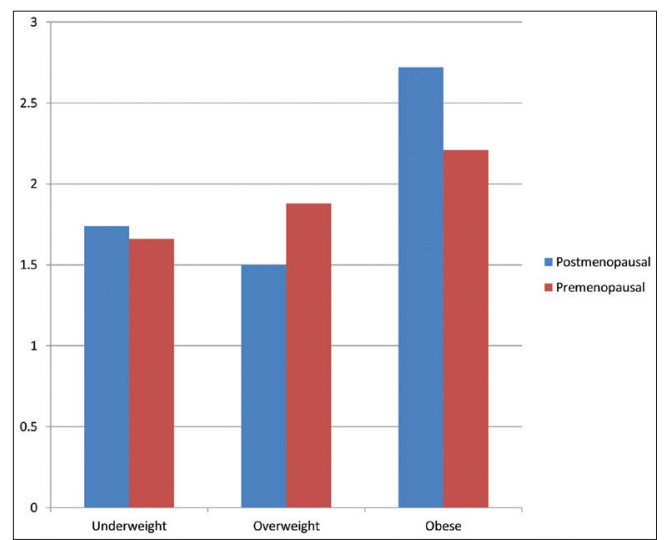

Figure I: Distribution of Odds Ratios and BMI categories in pre- and postmenopausal breast cancer risk among women

development in both pre- and postmenopausal Nigeria women.

\section{Discussion}

There was a significant difference between the heights of patients with breast cancer for all women collectively with controls, which shows that breast cancer risk is associated with increased height. This is in agreement with the findings of other studies in
Europe and Africa in which breast cancer risk was associated with increasing height in both pre- and postmenopausal women ${ }^{4,14,15}$ The increase in breast cancer risk seem to be associated with increase in height as expressed by Zhang et al. ${ }^{15}$ which showed that adult height is a risk factor for breast cancer in women and $10 \mathrm{~cm}$ increase in height was associated with a $17 \%$ elevated risk of breast cancer.The association between height and breast cancer risk may likely be due to a more complex interaction between genetic and environmental factors. ${ }^{4,15}$

Postmenopausal women obesity was a risk factor for developing breast cancer. ${ }^{16,17}$ As reported previously $8,14,16,17$ this study found that there was a statistically significant difference between the weight of controls [65.4 $\pm 9.3,<0.0 \mathrm{I}, \mathrm{Cl}=95 \%]$ and cases. $[66.3 \pm$ II.8<0.0 $\mathrm{I} \mathrm{Cl=95 \% ].} \mathrm{This} \mathrm{study} \mathrm{also} \mathrm{showed}$ statistically significant differences in BMI between cases [25.6 $\pm 4.8, p<0.00 I]$ and control $[25.1 \pm 4.0$, $\mathrm{P}<0.00 \mathrm{I}]$. The result is consistent with the results of studies by Dukyoo,et al. ${ }^{18}$ and Zhu et al. ${ }^{19}$

In this study, BMI were categorized into four (4) categories according to $\mathrm{WHO}$ classification 
namely: underweight $\left(\mathrm{BMI}<18.5 \mathrm{~kg} / \mathrm{m}^{2}\right)$; normal range $\left(18.5-24.9 \mathrm{~kg} / \mathrm{m}^{2}\right)$; overweight $\left(25-30 \mathrm{~kg} / \mathrm{m}^{2}\right)$; and obese $\left(\mathrm{BMI} \geq 30 \mathrm{~kg} / \mathrm{m}^{2}\right)$. The odds of developing breast cancer was 2.72 higher for postmenopausal obese women compared to obese women $(O R=2.39)$ when Pre- and post menopausal women were combined (Figure I) .

Findings from this study show that as BMI increases, the risk of breast cancer in postmenopausal women increases. Our results are consistent with work done by Iwasaki et al., ${ }^{14}$ Dukyoo et al., ${ }^{18}$ Rosilene.et al., ${ }^{20}$ and Cold et al. ${ }^{9}$ After menopause, being obese increases breast cancer risk. Women who were overweight or obese after menopause have a 30-60 percent higher breast cancer risk than those who were lean. ${ }^{16-17,21}$ Some studies have shown that fat tissue contains an enzyme called aromatase which converts hormones called androgens to estrogen which make women with higher BMI to have higher blood estrogen levels than leaner women ${ }^{22}$ which increases the chances of such women developing breast cancer compared to leaner women with lower estrogen levels. This explains some of the risk among postmenopausal women who were overweight.

The high risk of breast cancer associated with high BMI in postmenopausal women category in this study may also be attributed to high levels of insulin in their body. Women with high BMI tend to have higher levels of insulin compared to leaner women. ${ }^{23}$ Some studies ${ }^{24-26}$ have reported an association with an increased risk of breast cancer among postmenopausal women with high levels of insulin.

\section{I. Limitations}

The study examined the breast cancer risk in relation to BMI for premenopausal and postmenopausal lgbo women in two South East Nigeria states. Our results cannot be generalized to all women in Nigeria. The relationship between breast cancer and obesity was related to high estrogen levels in postmenopausal women, however, our study did not explore staging of breast cancer, or treatment modality in breast cancer as this was beyond the scope of the study.

\subsection{Recommendations}

Primary prevention measures such as increasing physical activity is important to modestly curtail the increasing burden of breast cancer. Other primary prevention methods include avoidance of greater BMI/obesity and avoidance of postmenopausal weight gain. More research on hormone replacement therapy (HRT) is recommended given that HRT increases the risk of breast cancer and there might be a possibility that menopausal women were on HRT.

\section{Conclusion and Implications for Translation}

Among the population, height, weight, and body mass index were associated with increased breast cancer risk. There was a positive association between $\mathrm{BMI}$ and breast cancer risk for both pre- and postmenopausal women, but the association was stronger among postmenopausal women.

\section{Compliance with Ethical Standards}

Conflicts of Interest: The authors declare that they have no conflict of interest. Financial Disclosure: None. Funding/Support: None. Ethics Approval: Ethical clearance was obtained from the Ethical Committiee at Abia State University Teaching Hospital, the Maranatha Specialist Hospital, and Federal University of Technology, Owerri, Imo State, Nigeria. Acknowledgements: The study team appreciates the support of the Doctors and the participants for their cooperation during the study.

\section{References}

I. Bray F, Ren JS, Masuyer E, Ferlay J. Global estimates of cancer prevalence for 27 sites in the adult population in 2008. Int. J. Cancer. 20 I 3; | 32(5): I | 33- I | 45.

2. Corsi DJ, Finlay JE, Subramanian SV. Weight of communities: A multilevel analysis of body mass index in 32,814 neighborhoods in 57 low to middle- income countries (LMICs). Social Science and Medicine. 2012;75(2):3 I I-22

3. World Health Organization (WHO). Nigerian Demographic Profile. 2014. https://www.who.int/ countries/nga/en/,Accessed 19 April, 2019.

4. Adebamowo CA, Ogundiran TO, Adeipekun E. Obesity and Height in urban Nigerian women with breast cancer. Ann Epidemiol. 2003;3:455-46I.

5. Ogundiran OT, Huo D, Adenipekun A, et al. Case- control study of body size and breast cancer risk in Nigerian women. Am. J. Epidemiol. 20I0; I 72(6):682-690.

๑ 2019 Global Health and Education Projects, Inc. 
6. Ogundiran OT, Huo D, Adenipekun A, et al. Body fat distribution and breast cancer risk: Findings from the Nigerian breast Cancer Study. Cancer Causes Control. 20I2; 23(4):565-574.

7. Lonning P, Haynes BP, Dowsett M. Relationship of body mass index with aromatization and plasma and tissue oestrogen levels in postmenopausal breast cancer patients treated with aromatase inhibitors. European Journal of Cancer. 20 I4;50: 1055-1064.

8. Robinson PJ, Bell RJ, Davis SR. Obesity is associated with a poorer prognosis in women with hormone receptor positive breast cancer. Maturitas. 2014;79(3)279-286.

9. Cold S, Hansen S, Overvad K, Rose C. A woman's build and the Risk of Breast Cancer. European Journal of Cancer. 1998;34: I 163-I I 74.

10. Baer HJ, Tworoger SS, Hankinson SE, Willett WC. Body fatness at young ages and risk of breast cancer throughout life. American Journal of Epidemiology. 2010;171:1183-1194.

II. Ferlay J, Soerjomataram I, Ervik M, Dikshit R, Eser S, Bray F. GLOBOCAN 2012 v 1.0 cancer incidence and mortality worldwide. 20I3; http//www.globocan. iarc.fr.

12. Kerlikowske K, Migloretti DL, Buist DM, Walker R, Carney PA. Decline in invasive breast cancer and use of post menopausal hormone therapy in a screening mammography population. I Nat Cancer Inst. 2007;99(17):1335-9.

13. IBM Corp. Released 20I5. IBM SPSS Statistics for Windows, Version 23.0. Armonk, NY; IBM Corp.

14. Iwasaki M, Otani T, Inoue M, Sasazuki S, Tsugane S. Body size and Risk for Breast cancer in Relation to Estrogen and Progesterone Receptor Status in Japan. Ann Epidermiol. 2007; I7(4):304-3I2.

15. Zhang B, Shu X, Delahanty RJ. Height and breast cancer risk: evidence from prospective studies and mendelian randomization. J Natl Cancer Inst. 2015;107(II):djv219. doi: I0.1093/jnci/djv219.

16. Huang Z, Hankinson SE, Colditz GA, et al. Dual effects of weight and weight gain on breast cancer risk.JAMA. 278; I407-II.
17. Reeves GK, Pirie K, BeralV, Green J, Spencer E, Bull D. Cancer incidence and mortality in relation to body mass index in the Million Women Study: cohort study. BMJ. 2007;335(7630): I 134.

18. Dukyoo J, Sun-Mi L. BMI and Breast cancer in Korean Women: A meta- Analysis. Asian Nursing Research. 2009;3(I):3I-40.

19. Zhu K, Caulfield J, Hunter S, Roland CL. Payne-Wilks K, Texter L. Body mass index and breast cancer risk in African American women. Ann Epidemiol. 2005; 5: 123-128.

20. Rosilene LP, Luis O, Aarao M, Pinto N. Relationship between body mass index, waist circumference and waist to hip ratio and the steroid hormone receptor status in breast carcinoma of pre- and postmenopausal women. The Breast. 2009; 8:8-12.

21. Van den Brandt PA, Spiegelman D, Yaun SS, et al. Pooled analysis of prospective cohort studies on height, weight, and breast cancer risk. Am J Epidemiol. 2000;152:5|4-27.

22. KeyTJ,Appleby PN, Reeves GK, et al.for the Endogenous Hormones and Breast Cancer Collaborative Group. Circulating sex hormones and breast cancer risk factors in postmenopausal women: reanalysis of 13 studies. Br J. Cancer. 20I I; I05(5):709-22.

23. Hvidtfeldt UA, Gunter MJ, Lange T, et al. Quantifying mediating effects of endogenous estrogen and insulin in the relation between obesity, alcohol consumption, and breast cancer. Cancer Epidemiol Biomarkers Prev. 2012;2I (7): I 203-12.

24. Michels KB,Solomon CG, Hu FB, et al.for the Nurses' Health Study. Type 2 diabetes and subsequent incidence of breast cancer in the Nurses' Health Study. Diabetes Care. 2003;26(6): I752-8.

25. Boyle P, Boniol M, Koechlin A, et al. Diabetes and breast cancer risk: a meta-analysis. $\mathrm{Br} J$ Cancer. 2012;107(9):1608-17.

26. De Bruijn KM, Arends LR, Hansen BE, Leeflang $S$, Ruiter R, van Eijck $\mathrm{CH}$. Systematic review and metaanalysis of the association between diabetes mellitus and incidence and mortality in breast and colorectal cancer. Br J Surg. 2013; I00(II): I42I-9. 